\title{
Emotions of Protest in Mark 11-13: \\ Responding to an Affective Turn in Social-Scientific Discourse
}

Louise J. Lawrence

'Emotions have disappeared from models of protest.'

-James Jasper, 'The Emotions of Protest:

Affective and Reactive Emotions in and Around

Social Movements'

In his 2011 article 'Eschatology and the Emotions in Early Christianity' Stephen Barton was among the first voices in biblical studies to respond to the so-called 'affective turn' in socialscientific discourse. In so doing he aimed to 'open up the question of the impact of early Christian belief and practice on the construction and display of the emotions . . . against the backdrop of cultures of the emotions in the Greco-Roman world'. ${ }^{1}$ Taking 1 Thessalonians 4:13-18 as a case study, he went on to demonstrate how Christian eschatological faith was transformed in multifaceted ways by the embodied experience of 'grief'. William Telford's classic study on The Barren Temple and the Withered Fig Tree (1980) implicitly acknowledged the importance of emotions when he underscored how (divine) wrath and anger lay behind the association of the cursing of the fig tree and Jesus' violent action in the temple. Both interrelated episodes ultimately, in his view, signalled eschatological judgement and curse. His work envisages Mark impressing on his readers the 'cultic aberration on the part of Israel' and its failure to produce fruit synonymous with the messianic age. ${ }^{2}$ Here I want to juxtapose Barton's attention to the emotions with Telford's close reading of the fig tree and temple incident to probe emotional dimensions of 'protest' encountered in the context of Mark chapters 11-13. For, as the sociologist James Jasper has shown, as a fundamental grounding of both social movements and actions, 'affective and reactive emotions enter into protest activities at every stage. ${ }^{3}$

\footnotetext{
${ }^{1}$ Stephen C. Barton, 'Eschatology and the Emotions in Early Christianity' Journal of Biblical Literature 130 (2011) 571-591. See also Renate Egger-Wenzel and Jeremy Corley (eds), Emotions from Ben Sira to Paul (Walter de Gruyter, 2012); Matthew A. Elliott, Faithful Feelings: Rethinking Emotion in the New Testament (Kregel Publications, 2006); Stephen Voorwinde, Jesus' Emotions in the Fourth Gospel (Bloomsbury T\&T Clark, 2005) and his Jesus' Emotions in the Gospels (London: T\&T Clark, 2011) though note the section on Mark in this book does not address chapters 11-13.

${ }^{2}$ William Telford, Barren Temple and the Withered Tree (Sheffield: Sheffield Academic Press, 1980), 135.

3 James Jasper, 'The Emotions of Protest: Affective and Reactive Emotions in and around Social Movements' Sociological Forum 13 (1998), 397-424, 405.
} 


\section{Emotions and the Affective Turn in Social-Scientific Discourse}

Whilst the 1970's 'textual' turn in social-science intentionally 'bracket[ed] out all pre- or extra-discursive reality' ${ }^{4}$ the 'affective turn' of the last decade (stimulated in part by queer and feminist theory) signals a renewed attention to the "material, embodied and sensory., 5 The textual paradigm which valued the rational and dialogical above all else is, in the affective turn, supplanted by a focus on the physical, performative, impulsive and responsive elements of the 'lived body' and the ways in which it intersects with and indexes cultural forms of power and knowledge. A definition of the emotions as 'felt judgments ${ }^{6}$ captures well the ways in which contemporary social-scientific studies, inflected by the 'affective', intentionally suffuse mind and body. Feeling/s conceived as both sensory/physical phenomena and sentiments/emotions thus render Cartesian-fed dualisms (mind/body; internal/external; psychic/social; physical/moral; biological/political) as erroneous. For 'if something is "touching" it moves us to feel; if we feel something we also touch it . . to feel deeply about something means to be "moved.", Feelings in this respect play important roles in social movements for they have the power to arouse affiliation and identification, exclusion and segregation. As such they function as evocative 'intensifications' or in Sarah Ahmed's terms 'emotional economies' ${ }^{8}$ which 'shape the surfaces of individual and collective bodies ${ }^{9}$ within cultural politics in general, and forms of protest against dominant cultural forms in particular.

\section{Emotions and Protest}

'Protest' as the Oxford English Dictionary asserts is a noun which denotes 'action[s] expressing disapproval of or objection to something' and as a verb, 'expression of an objection to what someone has said or done'. ${ }^{10}$ Given the intensity of 'feelings' (anger;

\footnotetext{
${ }^{4}$ Monica Greco and Paul Stenner 'Introduction' in Monica Greco and Paul Stenner (eds), Emotions: A Social Science Reader (London: Routledge, 2008), 1-21, 9.

${ }_{5}$ Marianne Liljeström, Susanna Paasonen, 'Introduction' in Marianne Liljeström, Susanna Paasonen (eds), Working with Affect in Feminist Readings: Disturbing Differences (Oxford: Routledge, 2010), 8-27, 1.

${ }^{6}$ David Lemmings and Ann Brooks, 'The Emotional Turn in the Humanities and Social Sciences' in David Lemmings and Ann Brooks (eds), Emotions and Social Change: Historical and Sociological Perspectives (New York: Taylor and Francis, 2014), 3-17, 3. On the conception of the emotions as (a) psychobiological elements or (b) purely socially constructed, see Catherine Lutz and Geoffrey M. White, 'The Anthropology of Emotions' Annual Review of Anthropology 15 (1986), 405-436.

${ }^{7}$ Stephen Frosh, Feelings (Oxford: Routledge, 2011), 1. See also Michael Hardt's comment that the affective involves 'equally the body and the mind ... reason and the passions'. See Michael Hardt 'Foreword' in Patricia Ticineto Clough, Jean Halley et al (eds), The Affective Turn: Theorizing the Social (Duke University Press, 2007), viii-xiii, ix.

${ }^{8}$ Sarah Ahmed, The Cultural Politics of Emotion (Oxford: Routledge, 2004) , 4.

${ }^{9}$ Ahmed, Cultural, 1.

${ }^{10}$ Oxford English Dictionary < http://www.oed.com/>
} 
indignation; alienation; fear; disgust; joy; love etc.) which such performances frequently involve, it is surprising as James Jasper noted writing in the late 1990's, to find so little attention given to emotions within social-scientific studies of protest. ${ }^{11}$ Jasper wondered whether overly-cognitive, rationalistic, textual models purposefully discounted (/denigrated?) consideration of emotional dimensions for suspicion (/fear?) it would render the act of protest itself as 'irrational': 'they trot out emotions only to study Nazis, moral panics and other movements they dislike. ${ }^{12}$ I am sure he was right. Now, however, in the wake of an 'affective turn' Jasper's general thesis that 'emotions accompany all social action, providing both motivation and goals ${ }^{13}$ is much more openly entertained. Moreover, his assertion that 'social movements are affected by transitory, context-specific emotions, usually reactions to information or events, as well as more affective bonds and loyalties' and that 'some emotions exist or arise in individuals before they join protest groups; others are reinforced in collective action itself ${ }^{14}$ seems reasonable. His versatile model of emotional dimensions of protest detailed below constitutes a useful heuristic tool with which one can start to 'feel' one's way around the 'emotional economies' of such movements.

Jasper starts by identifying an array of affective (more stable) and reactive (more transitory) emotions and moods which often constitute the emotional capital of protest movements. Whilst the employment of specific 'feelings' are of course culturally specific, nonetheless one can be confident that some sort of affective and reactive emotional resources are employed cross-culturally in movements of this sort.

\begin{tabular}{|l|l|l|}
\hline $\begin{array}{l}\text { Primarily Affective (Stable) } \\
\text { Emotions }\end{array}$ & $\begin{array}{l}\text { Primarily Reactive (Transitory) } \\
\text { Emotions }\end{array}$ & Moods and Others In Between \\
\hline $\begin{array}{l}\text { Hatred, Hostility, Loathing } \\
\text { Love, Solidarity, Loyalty } \\
\text { Suspicion, Trust, Respect }\end{array}$ & $\begin{array}{l}\text { Anger } \\
\text { Grief, Loss, Sorrow } \\
\text { Outrage, Indignation } \\
\text { Shame }\end{array}$ & $\begin{array}{l}\text { Compassion, Sympathy, Hope } \\
\text { Cynicism, Depression } \\
\text { Defiance, Resignation } \\
\text { Enthusiasm, Pride } \\
\text { Envy, Resentment } \\
\text { Fear, Dread } \\
\text { Hope, Joy }\end{array}$ \\
\hline
\end{tabular}

Emotions Relevant to Protest, Abstracted from James Jasper, $1996^{15}$

\footnotetext{
11 Jasper 'Emotions', 397-424

12 Jasper, 'Emotions' 420-421.

13 Jasper, 'Emotions', 397.

14 Jasper, 'Emotions', 397.

15 Jasper, 'Emotions', 406. The model presented here with certain abstractions and modifications.
} 
Jasper goes on to explore the social settings, both external and internal to the movement, which most usually develop and sustain affective and reactive emotions. Ongoing affects/loyalties outside the movement - love for kin; security of home; fear of war; trust in certain figures and mistrust of others and racial or other prejudices - are compared with those inside the movement - love/attraction to other members; loyalty to shared symbols/identity; respect/trust for leaders; trust/mistrust of those in power. These ongoing affects are also contrasted with responses to episodic events/information. Outside the movement these may include shock or anger/outrage over a decision made by those in power, or indignation/resignation. Within the movement this is more likely to be channelled into social action: anger and indignation is transformed into outrage and performances which the movement demands. ${ }^{16}$ Jasper also delineates notions encompassing the emergence, recruitment and endurance of protest movements. ${ }^{17}$ These include:

- Moral Shock: 'an event or piece of information raises such a sense of outrage ... [persons are] inclined toward action. ${ }^{18}$

- Blame: 'the ability to focus blame is central to protest.' 19

- Frame Alignment: 'during recruitment . . organizers and potential participants must "align" their "frames" achieving a common definition of a social problem and a common prescription for solving it. ${ }^{20}$

- Collective Identity: 'a sense of solidarity among members . . . an effective as well as cognitive mapping of the social world. ${ }^{21}$

- Membership Maintenance and Movement Culture: 'reciprocal and shared emotions reinforce each other, thereby building a movement's culture. 22

Whilst the above are not unfamiliar concepts in social-scientific discourse, they have, Jasper contends, for the most part been understood as 'structural' rather than 'emotional/affective' phenomena. His model redresses this imbalance and outlines ways that emotions give 'ideas, ideologies, identities and even interests their power to motivate' and underscores the point that once created, 'protest itself is filled with a variety of emotions. ${ }^{23}$ It is with these insights that we approach and interrogate the 'emotional economy' inherent within Mark chapters $11-13$.

\footnotetext{
${ }^{16}$ Jasper, 'Emotions', 407. The model is presented here with certain abstractions and modifications.

17 Jasper, 'Emotions', 408.

18 Jasper, 'Emotions', 409.

${ }^{19}$ Jasper, 'Emotions', 410.

${ }^{20}$ Jasper, 'Emotions', 413.

${ }^{21}$ Jasper, 'Emotions', 415.

22 Jasper, 'Emotions', 417.

${ }^{23}$ Jasper, 'Emotions', 420.
} 


\section{Emotions of Protest in Mark 11-13}

The temple, the heart of Israel's religious life, 'the symbol of national identity ${ }^{24}$ and potent 'emotional repository' 25 not only provides the dominant landscape but also the central ideological focus of 'protest' in these three chapters. Jesus' preparation for and entry into Jerusalem on a donkey (11:1-11) ends in the temple where 'he looked around at everything' therein (11:11). The next day, having cursed a fruitless fig tree (11:12-14), he again enters the temple to enact a protest against those who would make the 'house of prayer' a 'den of robbers' (11:17): '[he] began to drive out those who were selling and those who were buying in the temple and he overturned the tables of the money changers' (11:15-17). The next day the disciples note that the accursed fig tree is now withered completely (11:21). Jesus' actions and words unsurprisingly prompt hostility from the authorities and he is asked by them to account for his assumed 'authority' (11:27-33). These concerns are answered in a parable about violent tenants in a vineyard who, after killing slave messengers, finally kill the landowner's son (12:8). More questions follow regarding taxes (12:13-17), resurrection $(12: 18-27)$ and the greatest commandment (12:28-34). Jesus then sits again in the temple (12:35-44) and issues warnings against the scribes who garner honour for themselves on earth but who will ultimately 'receive the greater condemnation' (12:40). Next gazing at the temple treasury he singles out a poor widow's contribution as a foil for the rich: 'for all of them [the rich] have contributed out of their abundance; but she out of her poverty has put in everything ... she had to live on' (12:41-44). Exiting the physical space of the temple for the last time, Jesus delivers his apocalyptic prophecy of its destruction - 'not one stone will be left here upon another; all will be thrown down' (13:2). Referencing the emancipated fig tree $(13: 28-30)$ once more he underscores the imminence of divine judgement and the importance of readiness: 'you do not know when the master of the house will come, in the evening, or at midnight, or at cockcrow, or at dawn, or else he may find you asleep when he comes suddenly. And what I say to you I say to all: Keep Awake' (13:35-37).

\footnotetext{
${ }^{24}$ R. T. France, The Gospel of Mark: A Commentary on the Greek Text (William Eerdmans Publishing, 2002), 436.

${ }^{25}$ Stephen Barton, 'Why Do Things Move People? The Jerusalem Temple as Emotional Repository', unpublished paper kindly sent to me by the author. On temples in an Asian context, see Adam Yuet Chau, 'The Sensorial Production of the Social' Ethnos: Journal of Anthropology 73 (2008), 485-504.
} 
Within the course of these three chapters four main characters appear: (i) Jesus and (ii) the religious authorities who engage in conflict (iii) the crowd who remain an engrossed (if largely passive) onlooker and finally (iv) the disciples who play quite a minor role (with very few explicit emotions being attributed to them) but nonetheless function as the main recipients of Jesus' prophetic dialogue. Adopting Jasper's categorisations here I will attempt to chart the affective and reactive emotional dimensions and moods respectively assigned to the religious authorities and the crowds (who do not submit to the protest movement of Jesus) and contrast them to Jesus (and the disciples addressed by his teaching) who constitute the movement itself. As will be seen, the text explicitly cites some emotions and evokes others implicitly within its audience. A couple of caveats before I begin: Western glosses of 'emotions' of course do not make emotions themselves intelligible, culturally-specific evocations and ramifications need to be probed. Emotions should also not be understood as static, essential or objective, but rather are evident in specific interrelations between people, places and events; they are as Ahmed argues, inherently social:

Emotions create the effect of the surfaces and boundaries that allow us to distinguish an inside and an outside in the first place. So emotions are not simply something 'I' or 'we' have. Rather, it is through emotions or how we respond to objects and others, that surfaces and boundaries are made: the 'I' and 'we' are shaped by, and even take the shape of, contact with others. $^{26}$

\section{3a. The Crowd}

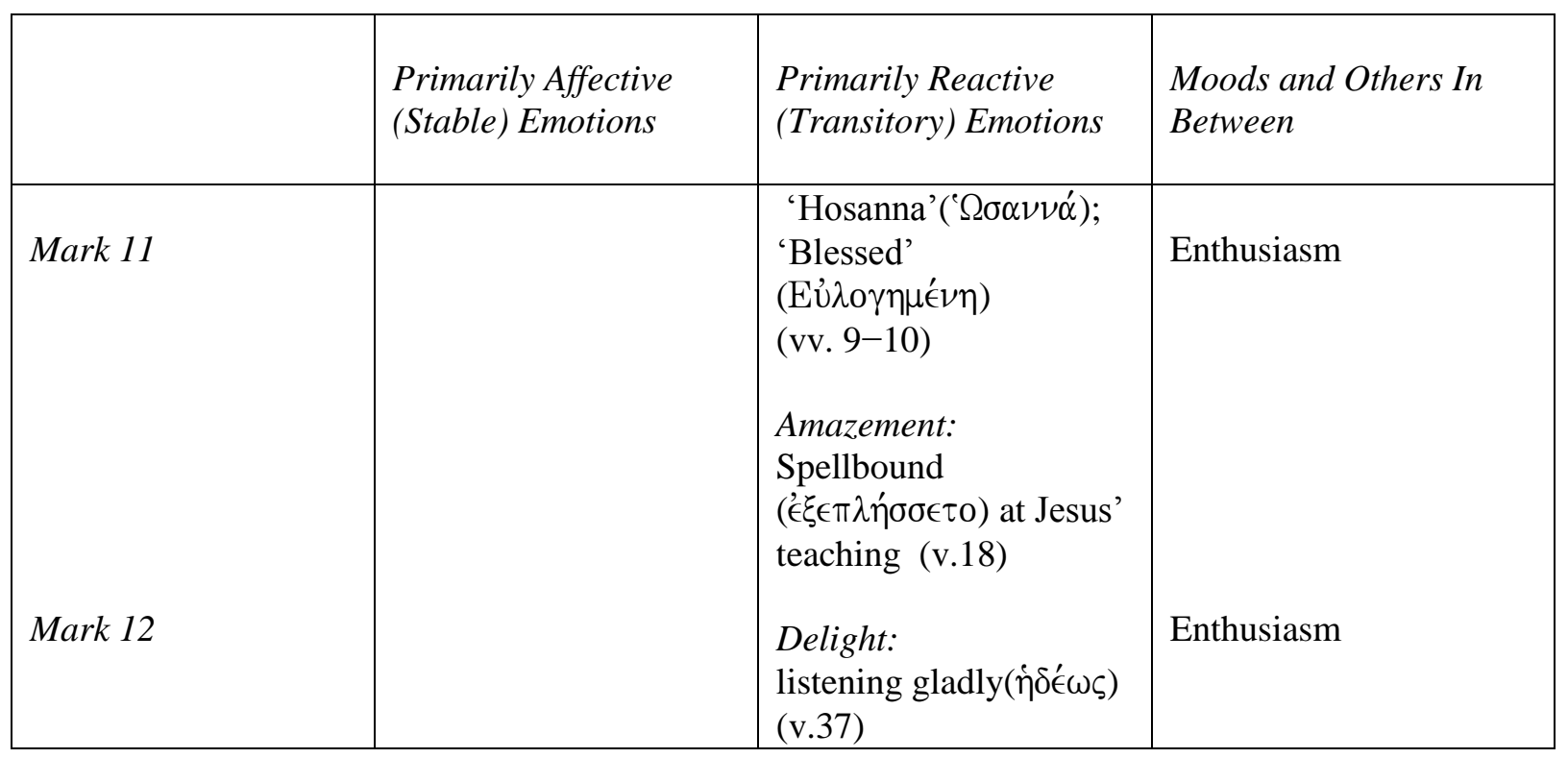

${ }^{26}$ Ahmed, Cultural, 10. 
As can be seen, the crowd are purely emotionally reactive to transitory events in this chapter - they shout in chorus, are absorbed by Jesus' teaching and listen gladly to it - but do not exhibit more enduring or stable affective states. Whilst enthusiastic throughout, a positive emotion that Jasper argues protest leaders frequently try to mobilise, ${ }^{27}$ in this instance the crowd is not galvanised enough to join his movement.

The crowd demonstrates intense emotional arousal (interest and excitement) in spreading cloaks and branches on the ground and their proclamation of 'Hosanna! Blessed is the one who comes in the name of the Lord' (v. 9-10). Michelle Duffy et al, have explored how rhythm, singing or shouting orientate bodies in spaces. Sounds can 'trigger embodied responses' and adrenaline-fuelled collective chanting can cultivate emotional ties in 'sites-ofbelonging. ${ }^{28}$ But, in this instance, the bonds are short-lived and make little enduring difference to the crowd's outlook. John Lofland in his study of 'crowd joy' significantly notes how such occasions 'can differ in the degree to which they are institutionalized' (predesigned, pre-planned and recurring). He notes that the most 'high' levels of 'pure collective behaviour' are when crowds do not follow a regularised 'social script' but rather convene in spontaneity or surprise. ${ }^{29}$ This directly prompts questions surrounding the nature of the crowd dynamics presented here.

Many commentators have identified the scene as a 'deliberate allusion to Zechariah's prophecy of the king who comes to Jerusalem riding on a donkey (Zech 9:9-10), ${ }^{30}$ and the term 'Hosanna' in its echoes of Psalm 118 as a plea for God to intervene and save. R. T. France, picking up on these echoes, impresses the campaigning fervour of the entry:

If then, Jesus chose, on this one occasion in his public life, to ride into the city, he was aiming to be noticed. The great outburst of praise and nationalistic sentiment which Mark records in vv.8-10 did not take him by surprise, and indeed he could be said to have engineered it, with his own disciples acting like cheerleaders. ${ }^{31}$

However, Robert Stein's contention that the 'Hosanna' formula's meaning and use had itself transformed (institutionalized?) by the first century into a more colloquial understanding is instructive. He writes, 'it was no longer understood literally as a cry by

\footnotetext{
${ }^{27}$ Jasper, 'Emotions', 410.

${ }^{28}$ Michelle Duffy et al, (eds), 'Bodily Rhythms: Corporeal Capacities to Engage with Festival Spaces' Emotion, Space and Society 4 (2011) 17-24, 17.

${ }^{29}$ John Lofland, Protest: Studies of Collective Behavior and Social Movements (New Jersey: Transaction Publishers, 2007), 73.

${ }^{30}$ France, Gospel, 429.

${ }^{31}$ France, Gospel, 429.
} 
those shouting it for God (or on this occasion perhaps for Jesus) to now save the people of Israel from their enemies. Being repeated by pilgrims each year at the various major festivals it had become idiomatic in nature and was by then an expression of joy and jubilation. ${ }^{32}$ This seems also to make more sense given the lack of lasting effect the chanting has on the people, and the fact it does not rouse or empower them to action. Stein also contends that 'Blessed is the one coming in the name of the Lord!' did not necessarily have messianic overtones, rather it was the common greeting for all pilgrims entering Jerusalem ${ }^{33}$ and thus is employed here, at least by the crowd (for Mark's listeners are in a privileged position to pick up deeper meanings regarding Jesus' identity) as familiar and routine, rather, than an extraordinary or protest-stimulating call. Morna Hooker makes a similar point when she states: 'as Mark tells the story [of the entry into Jerusalem] the incident is certainly not the unambiguous assertion of messiahship which later interpretation has made it, even though Mark regards it as clear enough to those with eyes of faith'. ${ }^{34}$ Here then it is a ritual, at least as enacted by the crowd, inflected with repetition and conservatism, rather than an unprompted, chaotic 'occasion for changes to break through. ${ }^{35}$

The crowd also listen with delight to Jesus' teaching (12:37) and 'amazement'

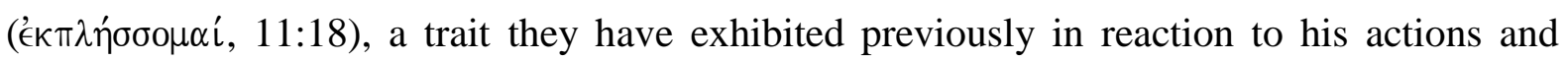

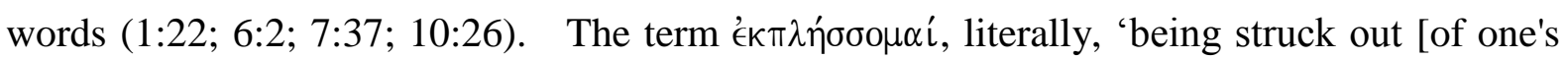
mind]' reflects both the sensory and somatic affects his violent actions and words in the temple have had on them as a whole group. Whilst the $N R S V$ translation 'spellbound' perhaps conjures up for contemporary readers ideas of a sort of 'hypnotic . . . emotional contagion',36 spread among the people, one should, given the fact that Mark references that that the chief priests and scribes were fearful of the influence Jesus had on the crowd (11:18), see it more as a potentially explosive emotionally-charged call to action against the status quo: 'The casual and conventional crowds may become acting crowds in some circumstances ... whose members engage in, or are ready to engage in, violence against a specific target - a person, a category of people, or physical property. ${ }^{37}$ Here however, the potential fervour soon dissipates and dies down. As William Lane notes, whilst 'the people are astonished ... there

\footnotetext{
${ }^{32}$ Robert H. Stein, Mark (Grand Rapids: Baker Academic, 2008), 505.

${ }^{33}$ Stein, Mark, 505.

${ }^{34}$ Morna Hooker, The Gospel According to St Mark (A\&C Black, 1991), 256-257.

35 Andrew Ross, Mixed Emotions: Beyond Fear and Hatred in International Conflict (University of Chicago Press, 2013), 47.

${ }^{36}$ John J. Macionis, Sociology (New Jersey: Pearson Education, 2007), 609.

${ }^{37}$ Diana Kendall, Sociology in Our Times (Belmont: Wadsworth Publishing Co., 2008), 617.
} 
is no indication that they have penetrated the veil of Jesus' messianic dignity'; ${ }^{38}$ similarly for Telford, 'amazement remains that of the unbeliever, or the one yet to be convinced. ${ }^{39}$ Ultimately then, the crowd display transitory reactive emotions of enthusiasm and awe, but are not mobilised into action in response to Jesus' actions or words.

\section{3b. Religious Authorities}

\begin{tabular}{|c|c|c|c|}
\hline & $\begin{array}{l}\text { Primarily Affective } \\
\text { (Stable) Emotions }\end{array}$ & $\begin{array}{l}\text { Primarily Reactive } \\
\text { (Transitory) Emotions }\end{array}$ & $\begin{array}{l}\text { Moods and Others In } \\
\text { Between }\end{array}$ \\
\hline Mark 11 & & 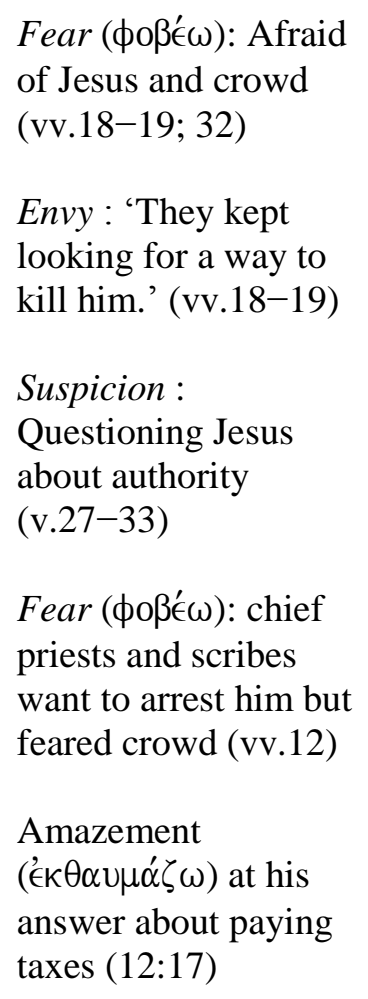 & $\begin{array}{l}\text { Envy/Resentment/ } \\
\text { Fear/Shame }\end{array}$ \\
\hline
\end{tabular}

The actions and words of Jesus 'effectively throw down the gauntlet to the Jerusalem authorities and force them to respond. ${ }^{40}$ Jesus completely dominates the narrative pace, space, script and action and the religious leaders in turn are purely reactive in their emotional economy. But whilst for the 'reactive' crowds the mood of response was primarily enthusiasm, here for the religious leaders, with the exception of 12:17 in which they are 'amazed' at Jesus' cryptic and clever answer regarding tax payment, the mood is

${ }^{38}$ William Lane, The Gospel According to Mark, (William Eerdmans Publishing Company; 2nd Revised edition, 1974), 408.

${ }^{39}$ Telford, 'Maze and Amazement in Mark's Gospel', The Way 41 (2001), 339-348, 347.

${ }^{40}$ France, Gospel, 428. 
overwhelmingly marked by envy, resentment and shame. Ahmed's designation of these emotions as responses to perceived menace or intimidation - 'the intensification not only of the bodily surface but also of the subjects' relation to itself, or its sense of the self ${ }^{41}-$ captures well the sense of threat and anxiety which these sorts of reactive emotions are ofttimes symptomatic. Furthermore, such reactions are written on bodies: shame, Ahmed contends 'consumes the subject and burns on the surface of bodies that are presented to others, a burning that exposes the exposure, and which may be visible in the form of a blush. $^{42}$

Throughout chapters 11-12 three main explicit emotions are embodied by the

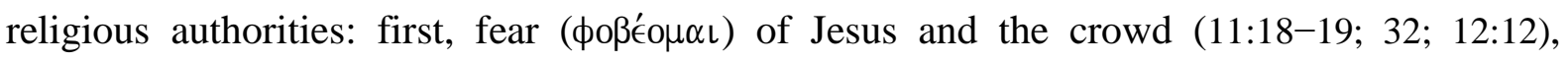
second, envy at Jesus' popularity which fosters aggression and a will 'to destroy ( $\left.\dot{\alpha} \pi \lambda^{\prime} \epsilon \sigma \omega \sigma \iota \nu\right)$ him' (11:18-19) and third, suspicion regarding the source of authority of Jesus' teaching (11:27-33). Of course these three responses are closely interlinked. Jerome Neyrey and Anselm Hagedorn captured this connectivity well when they characterised the action of Jesus in the temple as an invasion of "the physical space of the elite priests" ${ }^{43}$ and thus a challenge to their leadership of it, also in winning verbal ripostes set by them, Jesus effectively executed their public shaming. The image of limited good (goods, material and immaterial existing in finite supply), the agonistic nature of agrarian societies (competitive and suspicious of those outside the in-group) and the honour and shame complex in which one's reputation before others is of utmost importance was the cultural complex which made sense of the reactive emotions displayed. ${ }^{44}$ At 'the heart of envy [was] social comparison' and as Aristotle pointed out 'envy is felt chiefly towards those who are peers for reasons having to do with notions of social justice. ${ }^{45}$ Cultural beliefs surrounding the evil eye, the energy of the envier's gaze to deceive and destroy the object of their attention, are no doubt relevant here in probing the religious leader's covert homicidal intent. ${ }^{46}$

In paying attention to the circulation of 'hate' within the narrative compelling insights also emerge. Ahmed explored how 'feelings of injury get converted into hatred for others,

\footnotetext{
${ }^{41}$ Ahmed, Cultural, 104.

42 Ahmed, Cultural, 104.

${ }^{43}$ Neyery and Hagedorn 'It Was Out of Envy That They Handed Jesus Over' (Mark 15:10): The Anatomy of Envy and the Gospel of Mark, available online at <http://www3.nd.edu/ jneyrey1/envy.html> no pages.

${ }^{44}$ Neyery and Hagedorn 'Envy'.

${ }^{45}$ W. Gerrod Parrott 'The Emotional Experience of Envy' in Peter Salovey (ed), The Psychology of Jealousy and Envy (New York, Guilford Press, 1991), 3-28, 7.

${ }^{46}$ Neyrey and Hagedorn, 'Envy'.
} 
who become read as "causing injury.",47 On one level of course, the religious leaders posit Jesus as such an 'object of hate' and wish to deal with him once and for all. However, as their emotion is presented as purely 'reactive' within the narrative, it has no affective appeal on others, indeed over and again the concealment of emotions on the part of the religious leaders is underscored $(11: 18 ; 12: 12)$. However, if one conceives of hate circulating in the other direction in the emotional economy of this text, positing the religious leaders themselves as figures of hate, a different picture emerges. Ahmed talks about 'affect mov[ing] ... as fear becomes attached.' This process she writes 'involves a "sticky" quality that endows objects and signs with emotional significance.' In exploring hate crimes she shows how pain and fear can be "mutated into hatred . . through a process of repetition. ${ }^{48}$ These chapters effectively embody this process. By inscribing over and again the flat emotional traits of envy, fear, suspicion, resentment and shame, ultimately it is the religious authorities, rather than Jesus, who are dramatically altered into a 'common threat'. Moreover, the narrative projects negative emotions onto them as a group - internal dissent (11:30-33); hypocrisy (12:15); self-aggrandisement (12:38-40) - through Jesus' discourse or narrator comments. If objects of hate are indeed created by 'sticking' traits together to transform them into a common threat $^{49}$ - they are exposed as the villainous tenants in the parable $(12: 1-12)$ 'they devour

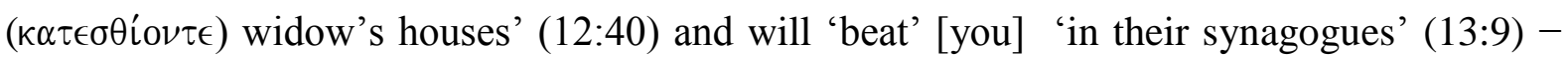
then these chapters do a sound emotional job of objectifying the religious leadership as such.

\footnotetext{
${ }^{47}$ Ahmed, Cultural, 15.

${ }^{48}$ Ross, Mixed, 44.

${ }^{49}$ Ahmed, Cultural, 15.
} 


\begin{tabular}{|c|c|c|c|}
\hline & $\begin{array}{l}\text { Primarily Affective } \\
\text { (Stable) Emotions }\end{array}$ & $\begin{array}{l}\text { Primarily Reactive } \\
\text { (Transitory) Emotions }\end{array}$ & $\begin{array}{l}\text { Moods and Others In } \\
\text { Between }\end{array}$ \\
\hline $\begin{array}{l}\text { Mark } 11 \\
\\
\text { Mark } 12 \\
\text { Mark } 13\end{array}$ & 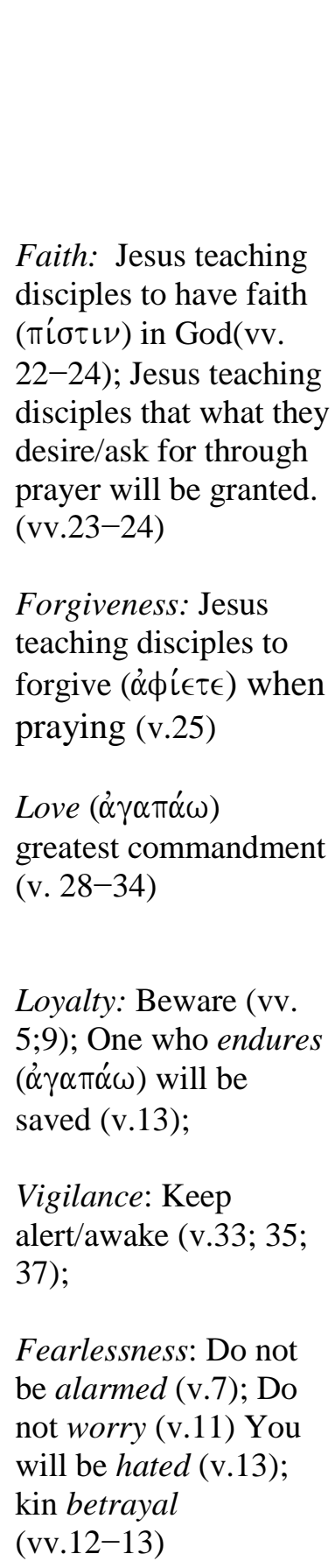 & $\begin{array}{l}\text { Anger/Indignation: } \\
\text { Cursing fig tree } \\
\text { (v.12-14) } \\
\text { Action in temple (vv. } \\
\text { 15-17) }\end{array}$ & Solidarity/Hope \\
\hline
\end{tabular}

What immediately becomes clear in the mapping of an emotional data-set, in marked contrast to the crowds and religious authorities, is how Jesus' teaching in these chapters is firmly grounded in affective emotional elements. The two instances where Jesus seems to respond to 
'transitory' events and embody 'episodic/reactive' emotions are the cursing of the fig tree $(11: 12-14)$ and the action in the temple (11:15-17). These two events eventually channel anger and indignation into more affective and stable emotional capital throughout chapters 11-12 where core moral values traditionally held up by the law: faith ( $\pi i \sigma \tau \iota \varsigma$ ) in God (11:22-24), belief ( $\pi\llcorner\sigma \tau \epsilon \cup ́ \omega)$ in the power of prayer (even to move mountains) (11:23-24), forgiveness ( $\dot{\alpha} \phi \dot{i} \eta \mu)$ (11:25) and love $(\dot{\alpha} \gamma \alpha \pi \dot{\alpha} \omega)$ of God and neighbour (v. 28-34) are celebrated as central emotional dispositions. Jasper commenting on the appeal to collective identities both within protest movements and as a potential recruiting tool notes how such demands are 'affective as well as cognitive mapping[s] of the social world. ${ }^{50}$ By drawing on core values which members held before joining a movement, 'protest becomes a way of saying something about oneself and one's morals, and of finding joy and pride in them, ${ }^{51}$

In chapter 13 the dialogue prompted by a disciple's question, turns the attention more firmly to emotions inside the movement. Mark's so-called 'little apocalypse', whilst as Ben Witherington has noted may not strictly fit an 'apocalyptic' genre - for it has no 'otherworldly mediator', 'visions of heaven or otherworldly tours' nor 'great quantities of apocalyptic verbiage or images or notions' - can nonetheless be seen as 'an example of late prophetic literature which includes some images and notions from apocalyptic discourse. ${ }^{52}$ Apocalyptic, the genre of 'protest literature ${ }^{, 53}$ par excellence inspires mobilization 'not as an objective or as a cognitive indicator of the odds of success, but as an emotional inspiration . . . a reassuring sign that history ... [is] on the side of the revolutionaries'. ${ }^{54}$ In Judith Diehl's terms such literature also frequently acts cathartically - 'a medical term . . . refer[ing] to the removal of a painful foreign object (or substance) from the body to promote the healing of the body ${ }^{55}$ - in diffusing and ameliorating anxiety and terror. It is no accident then that loyalty $(13: 5 ; 9)$, endurance $(13: 13)$ fearlessness $(13: 7 ; 11 ; 12-13)$ and vigilance $(13: 33 ; 35 ; 37)$ are here commended as core emotional values which foster hope and assurance that the movement will prevail, despite present or future indications to the contrary. The emotional economy of hope is of course central to all protest for as Ahmed states: 'hope is what allows

\footnotetext{
${ }^{50}$ Jasper, 'Emotions', 415.

${ }^{51}$ Jasper, 'Emotions', 415.

52 Ben Witherington, The Gospel of Mark: A Socio-Rhetorical Commentary (William Eerdmans Publishing Company, 2001), 337.

53 Judith Diehl, 'Anti-Imperial Rhetoric in the New Testament' in Scot McKnight and Joseph Modica (eds), Jesus Is Lord, Caesar Is Not: Evaluating Empire in New Testament Studies (Downer's Grove: Intervarsity Press, 2013), 38-81, 73.

${ }^{54}$ Jasper, 'Emotions', 416.

${ }^{55}$ Diehl, 'Anti-Imperial', 73.
} 
us to feel that what angers us is not inevitable, even if transformation can sometimes feel impossible ... the moment of hope is when the "not yet" impresses upon us in the present, such that we must act ... to make it our future. ${ }^{56}$

If then Jesus' discourse is firmly directed into solidarity and hope as articulated by affective emotions, what are we to make of the two trigger incidents, his cursing of the fig tree (11:12-14) and his actions in the temple (11:15-17)? These 'sandwiched' episodes have long been seen as mutually informing. Frequently commentators cite how the internal story (the temple incident) is explained by the outer constructions (the references to the fig tree). ${ }^{57}$ Variously therefore the real heart of the action is conceived of as in the temple, where either a cleansing of commercial/cultic practice or destructive divine judgement is forcefully performed on an unproductive cult system and/or people. ${ }^{58}$ Rather than engage well-trodden debates about the possible meanings suggested by these episodes, here I want to focus more on the (performative) 'hows?' of the encounter, by exploring the emotional dimensions of these activities. More specifically, the possibility that as 'national symbols' both fig tree and temple have potent appeal in the protest activities and emotional economy of this text and that Jesus' emotional triggers of anger and indigation play an important motivating role for others. For as Adam Winn rightly recognised: 'while the significance of Jesus' action in the temple can be debated, Jesus' authority and the power communicated through his action[s] cannot. $^{59}$

The performance of protest as Marcyrose Chvasta notes 'is emotive, ambiguous, and confrontational. Its liminality provides and points toward possibilities, different ways of being in the world ${ }^{60}$ whether that be 'boundary-crossing carnival' or intense 'anger to expose a wrong.' ${ }^{61}$ Two emotions are predominantly evoked in our text: Jesus' anger - 'visceral unease in reaction to information and events ${ }^{, 62}$ - and indignation - 'concerned with

\footnotetext{
56 Ahmed, Cultural, 184.

57 James Edwards, 'Markan Sandwiches: The Significance of Interpolations in Markan Narratives' Novum Testamentum XXXI, 3 (1989), 193-216, 196.

${ }^{58}$ Craig A. Evans is a representative of those who believes it is a 'cleansing' of an unclearn cultic system. See Craig Evans, "Jesus and the 'Cave of Robbers': Toward a Jewish Context for the Temple Action," Bulletin for Biblical Research 3 (1993), 93-110. E. P. Sanders, famously sees it as an eschatological symbolic destruction.. See E. P. Sanders, Jesus and Judaism (Fortress Press, 1985) famously sees it as an eschatological symbolic destruction.

59 Adam Winn, The Purpose of Mark's Gospel (Tubingen: Mohr Siebeck, 2008), 123.

60 Marcyrose Chvasta, 'Anger, Irony and Protest' available online at <http://www.csun.edu/ vcspc00g/301/AngerIronyProtest-Chvasta-TPQ.pdf > 12 .

${ }^{61}$ Chvasta, 'Anger', 13.

62 James Jasper 'Constructing Indignation: Anger Dynamics in Protest Movements' Emotion Review 6 (2014), 208-213, 210.
} 
defending dignity ${ }^{63}$ - which in Aristotle's terms evoked feelings for 'whatever is undeserved and unjust'. ${ }^{64}$ Both are emotions which have popularly (and prejudicially) been seen as uncharacteristically 'irrational and hot-headed' for Jesus. ${ }^{65}$ Anger and indignation as socialscientists have revealed can find outlets in 'radical ridicule" ${ }^{, 66}$ which specifically employs irreverent play within performances to 'question or re-envision ingrained social arrangements of power' ${ }^{67}$. Mikhail Bakhtin's notion of 'carnivalesque' brings to mind such elements when he sees specific (protest) performances dissolving all boundaries between spectators and performers and 'celebrat[ing] temporary liberation from the prevailing truth of the established order: it marks the suspension of hierarchical rank, privileges, norms and prohibitions. ${ }^{68}$

In order to start to unpack the emotional economy within these two actions, it is important first to note the temple and the fig tree's respective and evocative emotional appeal as "national symbols'. ${ }^{69}$ The temple was of course not only the dwelling place of the divine (Ps 132:13; Ps 9:11; Joel 3:17) but also the point of divine/human encounter and, through Jewish cultic rituals, the dispenser of law and justice. It is no accident then that prophetic traditions frequently evoked both anger and indignation if religious devotion was not attended to with the appropriate spirit of justice (Isa 1:10-17; Hos 6:6; Amos 5:21) ${ }^{70}$ The fig tree also fused diverse elements in its cultural repertoire and, to intentionally employ an anachronistic yet hopefully apt image, variously functioned as a 'planted flag' - in which 'a seemingly static and mute landscape [object] assumes life, expressing the cultural, economic, and legal dynamics that constantly shape and reshape it. ${ }^{71}$ It was used as an emblem for Israel's covenant relationship: the productivity of the nation was shown in the fruits of the figs (Hos 9:10) or its failure in the lack of them (Mic 7:1). Moreover the (eschatological) hope of national prosperity and peace was embodied in the image of 'each man under his own vine

${ }^{63}$ Robert B. McNeilly, Healing the Whole Person: A Solution-Focused Approach to Using Empowering Language (John Wiley and Sons, 2000), 70.

${ }^{64}$ Aristotle cited in Warren Frederick Morris, Emotion and Anxiety: A Philosophic Inquiry (Xlibris, 2006), 18.

${ }^{65}$ Krish Kandiah, Back to the Source: 30 Challenges to Live Like Jesus (Monarch Books, 2013), 167.

${ }^{66}$ A term taken from the subtitle of L. M. Bogad, Electoral Guerrilla Theatre: Radical Ridicule and Social Movements (London: Routledge, 2005).

${ }^{67}$ Jan Cohen-Cruz, 'Introduction' in Jan Cohen-Cruz (ed), Radical Street Performance: An International Anthology (Routledge, 1998), 1-7. 1.

${ }^{68}$ Bakhtin cited in Silvija Jestrovic, Performance, Space, Utopia: Cities of War, Cities of Exile (Palgrave Macmillan, 2012), 51.

${ }^{69}$ See David A. Butz, 'National Symbols as Agents of Psychological and Social Change' Political Psychology 30 (2009), 779-804.

70 'Temple' in Leyland Ryken (et al) (eds), Dictionary of Biblical Imagery (Intervarsity Press, 1998), 849.

${ }^{71}$ Irus Braverman, Trees as 'Planted Flags': Trees, Lands and Law in Israel/Palestine (Cambridge: Cambridge University Press, 2014). See <http://www.cambridge.org/gb/academic/subjects/law/socio-legal-studies/planted-flags-trees-land-and-lawisraelpalestine> 
and fig tree' (1 Kings 4:25; see also Zech $3: 10$; Mic 4:4; 7:1). ${ }^{72}$ Both temple and fig tree therefore stood as important 'collective imaginaries' or in Sherry Ortner's terms 'key symbols' which could 'catalyze the feelings and emotions of a group's members' and sustain collective identities even if people were physically dispersed. ${ }^{73}$ They both harboured an innate ability to 'condense meaning' and variously evoked 'an entire constellation of ideas and emotions. ${ }^{, 74}$

It is no surprise then that such national symbols should also constitute powerful and emotive sites in times of protest, often featuring in 'the most direct and radical style of the protest function, ${ }^{75}$ through deliberate assault or mutilation. For, as Nadia Seremetakis argues 'meaning-endowed objects bear within them emotional and historical sedimentation that can provoke and ignite gestures, discourses and acts.' 76 Karen Cerulo reveals that attacks on national symbols often transpire in contexts where people feel 'most severed from power'. ${ }^{77}$ Moreover, 'because national symbols are embodiments rather than mere representations, marring or defacing them, serve as direct denunciation[s] of both the leaders who control these symbols and the ideals those leaders have attached to the symbols. ${ }^{78}$ Many commentators have of course picked up on the deliberate impact Jesus' actions would assumedly have had on the religious authorities. Morna Hooker for example, noted that in purposefully inserting this tradition towards the closing stages of Jesus' life, Mark presents it as the pinnacle of Jesus' claim to authority over and against the religious establishment. She writes: ${ }^{79}$

His [Jesus'] action ... [was] a protest against the way in which a concern with the outward niceties of religion (the insistence that the sacrificial animal must be without blemish, guaranteed pure, and the temple taxes were paid in the appropriate currency) led to other realities being ignored . . . in other words, his protests about the priest's activities is exactly on a parallel with his protests about the teaching of the scribes and Pharisees,

\footnotetext{
72 'Fig Tree' in Ryken, Dictionary, 283-284.

${ }^{73}$ Michael E. Geisler 'Introduction: What are National Symbols?' in Michael E. Geisler (ed), National Symbols, Fractured Identities: Contesting the National Narrative (Middlebury College Press, 2005), xxi-xlii, xxv. Sherry Ortner cited in Tamar Mayer, 'National Symbols in Jewish Israel' in Geisler, National, 3-34, 3.

${ }^{74}$ Serena Nanda and Richard Warms, Culture Counts: A Concise Introduction to Cultural Anthropology (Wadsworth: Cengage Learning, 2009), 29.

${ }^{75}$ Karen A. Cerulo, Identity Designs: The Sights and Sounds of a Nation (New Jersey: Rutgers University Press, 1995), 31.

${ }^{76}$ Nadia Seremetakis 'The Memory of the Senses' in Nadia Seremetakis (ed), The Senses Still: Perception and Memory as Material Culture in Modernity (Westview Press, 1996), 1-22, 7.

${ }^{77}$ Cerulo, Identity, 31.

${ }^{78}$ Cerulo, Identity, 31.

${ }^{79}$ Hooker, Mark, 263.
} 
hardly surprising then if the outcome was a collusion between the priests and scribes. ${ }^{80}$

In this sort of case, the protester uses symbols in Cerulo's terms, to 'take command of them' and thus appropriate the symbolic power inherent within them for their own cause. As a direct consequence, 'by making the ruling elites the receivers rather than transmitters of the symbol, protestors inject their group with the national symbol's power . . . social control from below. ${ }^{, 81}$ However, in this text, the national symbols do not seem to be merely reattributed, but rather rendered completely extinct: the fig tree is not just wilted, it is irreversibly withered to its roots (11:20, '́ $\xi^{\prime} \eta_{\rho} \alpha \nu \tau \alpha$, literally dried up, scorched and stiffened) and the temple ultimately will have 'not one stone left upon another, all will be thrown down' (13:2).

Hans Dieter Betz seems to be more attune to the extreme and carnivalesque suspension of social order in this action, when he argues that Jesus' act was a radical, not merely a critical, protest: 'His action was not part of the regular temple ritual: it was not an even a ritual itself, but a one-time performance of a single individual. It can be characterised as a violent intervention, disrupting what other people regarded as normality. As confrontation and provocation the action was meant to be symbolic or paradigmatic. ${ }^{82}$ Jesus deliberately and jarringly employs explosive verbal denunciations on the fig tree (11:14) which is changed from a rooted, leafy tree to a shrivelled and scorched one, and the temple which is ideologically transformed from a 'house of prayer for all nations' to 'a den of thieves $(\lambda \eta\rceil \tau \omega \nu)$ ' $(11: 17)$ or more specifically 'insurrectionists'. In reference to this term, France notes:

its use here $[\lambda \eta \sigma \tau \hat{\omega} \nu]$ is because of the memorable LXX phrase . . recalled the prophets denunciation in his great Temple Sermon of the misplaced confidence of those whose behaviour belied their profession of respect for the temple. .... Jesus' use of the phrase accuses the Jews of his day of the same crimes as Jeremiah's contemporaries (including robbery) but highlights their lack of respect for God's house by comparing it with that flagrant abuse of the sanctuary. ${ }^{83}$

Ironically then, whilst Jesus in his non-linguistic embodied actions could be perceived as an 'insurrectionist' - effectively using violence to 'invest [his] body with agency' and in

\footnotetext{
${ }^{80}$ Hooker, Mark, 264.

${ }^{81}$ My italicisation, Cerulo, Identity, 29.

${ }^{82}$ Hans Dieter Betz, Antike und Christentum (Tubingen: Morh Siebeck, 1998), 62.

${ }^{83}$ France, Gospel, 446.
} 
Ahmed's terms, 'shaping the surface ${ }^{, 84}$ of temple space into a territory of his own body - he nonetheless labels those inside as such. This chimes with those who interpret specific protest acts as 'performative expressions of anger' and note how these frequently 'carnivalesque tactics' are utilized to transform anger into irony. Irony can 'mock, attack and ridicule, exclude, embarrass and humiliate ${ }^{85}$ and in the specific context of 'national symbols' can effectively facilitate transformations of them into satirical 'disordered objects'.

There are of course a number of other ironic tactics operating within the narrative which also serve to effect this change. The fig tree is cursed for not bearing fruit to satisfy Jesus' hunger despite ironically it 'not being the season for figs' $(11: 13){ }^{86}$ The reference to 'hunger' here is important and deliberately inscribes Jesus' body as 'an articulate signifying agent $^{87}$ which effectively objectifies the fig tree as 'disordered': it is incapable of satisfying his need and will thus be accursed. Jesus also goes into the temple and overturns tables of money changers, seats of dove sellers and 'would not allow anyone to carry anything through the temple' (11:15-16) which given the physical dimensions and crowdedness of the building must surely be received as ironic hyperbole. Betz's eminently sensible question of how 'in reality could one person disrupt the extensive business conducted by many merchants in the . . . outer courtyards of the temple area?' demonstrates this. Additionally, Betz's contention that 'in the real world we would expect the merchants would have quickly stopped Jesus' action, protected their merchandise and called in temple guards' seems highly probable. Betz concludes, 'if the merchants did none of this the action must have been insignificant. But if it were insignificant, how could it have attracted so much attention? ${ }^{88}$ If however, received ironically, the almost unimaginable interference created by one body here demonstrates the inherent vulnerability, feebleness and terminal decline of the entire institution; for 'irony invokes notions of hierarchy and subordination, judgement and moral superiority. ${ }^{89}$ Here the emotionally-saturated space of the temple evoking 'past, familiarity, belonging and safety' is

84 Ahmed, Cultural, 70.

85 Linda Hutcheon, Irony's Edge: The Theory and Politics of Irony (Taylor and Francis, 2005), e-edition, no pages.

86 Hooker, Mark, 262. See also Jerry Camery-Hoggatt, Irony in Mark's Gospel: Text and Subtext (Cambridge: Cambridge University Press, 2005), 69-70.

87 Susan Leigh Foster, 'Choreographies of Protest', Theatre Journal 55 (2003), 395-412, 396.

88 Hans Dieter Betz, 'Jesus and the Purity of the Temple (Mark 11:15-18): A Comparative Religion Approach' Journal Biblical Literature 116 (1997), 455-472, 456.

89 Chamberlain cited in Hutcheon, Irony's, no pages. 
objectified as errant as a result of particular configurations of social scripts, the performance of the actor present and the staging, ${ }^{90}$ of that space.

Throughout the entire episode, Jesus is shown to intentionally act from anger and indignation, the "prototypical protest emotions' ${ }^{91}$ and through re-categorising the national symbols of fig tree and temple as ironic 'objects of disorder' starts 'to create moral outrage and anger [in others] and to provide a target against which these can be vented. ${ }^{92}$ Whilst fear fosters passivity, anger generates and stimulates action by "put[ting] fire in the belly and iron in the soul. ${ }^{93}$ It is in this respect that the protest should be seen not as narrowly addressed to a particular group (whether that be as commentators have variously proposed 'the Jewish crowds, the Jewish religious leaders, the Temple, the sacrificial worship enacted in the temple, Israel as God's people, Judaism as a religious system, ${ }^{, 94}$ ) but rather a more multivocal performance. Peter Richardson has noted how many anthropological studies have noted how protestors employ 'both subtle as well as overt acts to convey their point' and as such protest is frequently received differently by different audiences. ${ }^{95}$ Like the thief in the strong man saying, 'Jesus breaks "into the House", 96 and through 'irreverent play' manages to perform socially explosive actions which are a powerful catalysts for some (the disciples are urged to follow and the crowd are spellbound by him 11:18), yet for others presumably they were perceived as the chaotic motions and ramblings of a madman. George Aichele elegantly captured this mixed reception, and complexity inherent in the oft-cited sandwich structure of the narrative, when he stated:

The unreasonableness of Jesus' violence in the temple is emphasised by the unseasonableness of his expectations from the fig tree . . because of its juxtaposition ... the cursing of the fig tree becomes more significant, and tells the reader more about Jesus than it would otherwise. Conversely the cleansing of the temple becomes less significant - just another violent outburst by a man who curses trees. ${ }^{97}$

\footnotetext{
${ }^{90}$ G. Brown, G. and J. Pickerill, 'Space for emotion in the spaces of activism' Emotion, Space and Society 2 (2009), $24-35,29$.

${ }^{91}$ Bert Klandermans, 'Framing Collective Action' in Kathrin Fahlenbrach (et al) (eds), Media and Revolt: Strategies and Performances from the 1960s to the Present (Berghahn Books, 2014), 41-57, 51.

${ }^{92}$ Klandermans, 'Framing', 51.

${ }^{93}$ Gamson, William A. Talking Politics (Cambridge: Cambridge University Press, 1992), 32.

${ }^{94}$ John Donahue and Daniel Harrington (eds), The Gospel of Mark (Collegeville, MN: Liturgical Press, 2002), 331.

${ }_{95}^{95}$ Peter Richardson, Building Jewish in the Roman East (Baylor UniversityPress, 2004), 18.

96 George Aichele, 'Jesus' Violence' in George Aichele and Tina Pippin (eds), Violence, Utopia and the Kingdom of God: Fantasy and Ideology in the Bible (Routledge, 1998), 72-90, 84.

97 Aichele, 'Jesus' Violence', 85.
} 
Activists frequently 'deploy apparatuses to create anger during interactions, and to display it to audiences. 98 Affronted dignity (indignation) can eventually be routed into passionate outrage and assurance. In the emotional economy of Jesus in these chapters we have identified this sort of pattern: the one aroused by reactive emotions of anger and indignation, must then through more stable affective bonds including loyalty in the face of violence, fearlessly endure. For only those who demonstrate such emotional capacities 'to the end will be saved' (13:13).

\section{The Affective Turn and Emotions of Protest in Mark 11-13}

The 'affective turn' signified a move to take seriously the sensory, performative and somatic encounters of the 'lived body' and in so doing question Cartesian dualisms of mind/flesh, internal/external, reason/emotions. ${ }^{99}$ Michelle Rosaldo consequently described emotions as "embodied thoughts, seeped with the apprehension that "I am involved", 100 meaningfully felt in 'flushes, pulses, movements of our livers, minds, hearts, stomachs and skin.' 101 'Feelings' towards emotions have hitherto been pretty thin in biblical studies, yet biblical texts are redolently marked by such interests. Commenting on the book of Job for instance, Harm van Grol rightly asserts:

We are not informed about the nature of his sin, his illness . . obviously the text was not written to inform us. This vagueness which irritated "enlightened" scholars in Western Europe disappears if it is about emotions . . . but that was a non-topic for these bourgeois academics. They characterized the description of emotions as hyperboles and Near Eastern exaggerations. Ironically these emotions are depicted with sharpness and one does not need an academic education to discern them. Maybe these texts were written to involve us. ${ }^{102}$

Barton's recent call for attention in biblical studies to the emotions in general and socialscientific treatises on the emotions in particular, is both timely and crucial in this respect. He recognised how such accounts could highlight ways in which emotions variously

\footnotetext{
98 Jasper, 'Constructing', 212.

99 Melissa Gregg and Gregory Seigworth, 'An Inventory of Shimmers' in Melissa Gregg and Gregory Seigworth, (eds), The Affect Theory Reader (Duke University Press, 2010), 1-27, 1.

100 Michelle Rosaldo, 'Toward an Anthropology of Self and Feeling' in R. A. Shweder and R. A. LeVine, Culture Theory: Essays on Mind, Self, and Emotion (Cambridge: Cambridge University Press, 1984), 137-157, 143.

${ }^{101}$ Rosaldo, 'Toward', 143.

${ }^{102}$ Harm van Graol, 'Emotions in the Psalms' in Egger-Wenzel and Corley, Emotions, 69-101, 76.
} 
'communicate culturally mediated moral judgments'; ${ }^{103}$ 'arise in the course of social relation and actions'; ${ }^{104}$ 'draw attention to the importance of certain kinds of practice, especially moral-legal and ritual practice'; ${ }^{105}$ the 'ways in which words and things offer symbolic resources for Christianity's distinctive emotional rationality'; how emotions 'are bodily and related to attitudes to the body' ${ }^{106}$ and most importantly how emotions are 'generated between bodies' and 'express individual and group identity in the context of social engagement and process' ${ }^{107}$ In this light, Mark 11-13 does important affective work in constructing an emotional economy of protest: 'it taps into . . moral sensibilities and involves powerful emotions'. 108 'Moral shock' is induced through the ironic re-positioning of central national symbols as 'disordered objects' and accordingly outrage and indignation are stimulated on account of these. Blame is not only projected onto immaterial objects of temple and fig tree, but also through the specific repetitions (in Ahmed's terms, 'sticking') of negative emotional responses (envy, fear etc.) on the religious leaders themselves, so much so that they effectively are transformed into objectified targets of 'hate' who should be guarded against, and who will ultimately 'receive the greater condemnation' (12:40).

Frame alignment, the process whereby 'leaders make their activities, ideas, and goals congruent with the interests, beliefs and values of potential new recruits ${ }^{109}$ is particularly seen in the predominant use of affective/stable emotions by Jesus within teaching discourses to the disciples, and more generally. By accentuating and celebrating common values upheld in the law (faith; belief in the power of prayer; love for God and neighbour) the importance of the positive beliefs the movement stands for are continually re-emphasised. Collective identity, not only "a sense of "we-ness" or "one-ness" that derives from perceived shared attributes' but more importantly "pre-requisites for collective action"110 is particularly sharpened in the discourse of chapter 13 where the importance of loyalty and endurance in the face of suffering and persecution are accentuated. 'The way' whether that be understood as a "prophetic reconfigur[ation] of the New Exodus imagery into an eschatological

\footnotetext{
${ }^{103}$ Barton , 'Eschatology', 579.

${ }^{104}$ Barton, 'Eschatology', 579.

${ }^{105}$ Barton, 'Eschatology', 579.

${ }^{106}$ Barton, 'Eschatology', 579

${ }^{107}$ Barton, 'Eschatology', 580.

108 James Jasper 'Recruiting Intimates, Recruiting Strangers: Building the Contemporary Animal Rights Movement' in Jo Freeman and Victoria Johnson (eds), Waves of Protest: Social Movements Since the Sixties (Maryland: Rowland and Littlefield Publishers, 1999), 65-82, 68.

109 Robert Brym and John Lie. Sociology: Your Compass for a New World (Wadsworth: Cengage Learning, 2010), 444.

${ }^{110}$ Catherine Corrigall-Brown, Patterns of Protest: Trajectories of Participation in Social Movements (California: Stanford University Press, 2012) e-book, no pages.
} 
pilgrimage to the temple' ${ }^{111}$ or 'the way of suffering (a via dolorosa), 112 it is unquestionably a 'way' which will be journeyed together, and by this 'physical co-presence of other participants, protestors realize that they are part of a greater whole.' 113

Emotions and feelings are undeniably 'implicated in historical and social change, ${ }^{\text {114 }}$ and thus provide 'rich territories' for probing the ideologies and performances of individuals and groups. Similarly, protest is never an 'occupier' of a neatly defined social, political, religious or other monolithic space; it is on the contrary lived and breathed both individually and in the collective. The author of the Gospel of Mark undoubtedly realised the significance of bolstering the emotional economy of his 'good news' when he wrote amidst social destruction, discrimination and persecution. Mark 11-13 with its powerful protest actions which channel anger and indignation into hope, solidarity and expectant vigilance thus speaks profoundly to that wider context of tortured, desperate and enduring lived bodies who were likewise urged to 'Keep alert', awake, fearless and faithful in what sometimes must have felt a very uncertain present.

111 Timothy C. Gray, The Temple in the Gospel of Mark: A Study in Its Narrative Role (Tubingen: Mohr Siebeck, 2008), 16.

${ }^{112}$ Gray, Temple, 19. In these chapters the trigger emotions of anger and indignation are activated for the sake of collective empowerment, later in the gospel, the display of hurt and victimization will also be strategically employed in the passion.

${ }_{113}$ Dunya van Troost et al, 'Emotions of Protest' in Nicolas Demertzis (ed), Emotions in Politics: The Affect Dimension in Political Tension (Palgrave Macmillan, 2013), 186-202, 198.

${ }_{114}$ David Lemings and Ann Brooks, 'The Emotional Turn in the Humanities' in (eds), Emotions and Social Change: Historical and Sociological Perspectives (Taylor and Francis, 2014), 3-17, 4. 